\title{
ORIENTASI KEWIRAUSAHAAN, INOVASI, DAN STRATEGI BISNIS UNTUK MENINGKATKAN KINERJA PERUSAHAAN (STUDI PADA UKM SENTRA KABUPATEN MALANG)
}

\author{
Rita Indah Mustikowati \\ Email : rita_fairuz@yahoo.com \\ Irma Tysari \\ Email : irmatyasari@yahoo.co.id
}

\begin{abstract}
Abstrak: Penelitian ini bertujuan Untuk mengetahui pengaruh langsung dari orientasi kewirausahaan kinerja perusahaan, mengetahui pengaruh langsung dari inovasi terhadap kinerja perusahaan, dan mengetahui pengaruh langsung dari strategi bisnis terhadap kinerja perusahaan. Populasi dalam penelitian ini adalah seluruh UKM Sentra Di Kabupaten Malang, jumlah sampel yang digunakan pada penelitian ini sebesar 82,394 UKM (pembulatan 100 UKM). Pengambilan sampel dilakukan dengan metode probability sampling, dengan teknik Proportional Random Sampling, yaitu pengambilan sampel secara proporsional untuk masing - masing wilayah. Data primer dikumpulkan melalui penyebaran kuesioner kepada responden, yaitu pemilik atau manajer dari Usaha Kecil Menengah, dengan berdasarkan pada instrumen penelitian. Sedangkan data sekunder diperoleh melalui Pemerintah Kabupaten Malang dan Dinas Kabupaten bidang usaha kecil menengah, BPS, serta instansi terkait. Metode analisis data yang digunan dalam penelitian ini adalah Regresi Berganda. Berdasarkan hasil pengujian hipotesis menunjukkan bahwa inovasi berpengaruh secara langsung dan positif terhadap kinerja perusahaan. Selanjutnya, hasil penelitian ini juga menemukan bahwa strategi bisnis akan mempengaruhi pencapaian kinerja perusahaan. Hal ini bermakna bahwa semakin kuat orientasi kewirausahaan, inovasi dan strategi bisnis yang dimiliki oleh perusahaan, maka akan meningkatkan kinerja perusahaan.
\end{abstract}

Kata Kunci : Orientasi Kewirausahaan, Inovasi, Strategi Bisnis, Kinerja Perusahaan, UKM Sentra

Rita Indah Mustikowati, adalah Dosen Prodi Akuntansi Fakultas Ekonomi Universitas Kanjuruhan Malang

Irma Tyasari, adalah Dosen Prodi Akuntansi Fakultas Ekonomi Universitas Kanjuruhan Malang 


\section{PENDAHULUAN}

Sebagai sebuah organisasi bisnis yang bersifat mandiri, UKM Mempunyai peranan yang penting dalam pertumbuhan ekonomi dan industri suatu negara (Husband dan Purnendu, 1999; Mahemba, 2003; Tambunan, 2005). Disamping itu, UKM mempunyai kontribusi terhadap penyerapan tenaga kerja (Tambunan, 2005). Studi empirik menunjukkan bahwa UKM pada skala internasional merupakan sumber penciptaan lapangan pekerjaan (Olomi, 1999; Westhead dan Cowling, 1995). Kontribusi UKM terhadap penyerapan tenaga kerja, baik di negara maju maupun negara berkembang, termasuk Indonesia, mempunyai peranan yang signifikan dalam penanggulangan masalah pengangguran.

Meskipun demikian, potensi yang dimiliki oleh UKM tidak diimbangi dengan kemampuan untuk bersaing. Tambunan (2008) mengungkapkan suatu fakta bahwa daya saing yang rendah dari UKM menyebabkan kelompok ini mengalami kesulitan dalam meningkatkan outputnya. Beberapa peneliti menjelaskan bahwa ketidakmampuan UKM dalam meningkatkan daya saing disebabkan karena UKM memiliki berbagai keterbatasan, seperti kurangnya kemampuan untuk beradaptasi dengan lingkungan, kurang cekatan dalam peluang - peluang usaha, kurangnya kreativitas dan inovasi dalam mengantisipasi berbagai tantangan lingkungan. Disamping itu, secara internal UKM kurang mempunyai kemampuan manajerial dan keterampilan dan kurangnya permodalan dan pasar. Disatu sisi, kajian literatur menjelaskan bahwa terdapat tiga aspek kunci yang akan menentukan daya saing dan dapat berdampak pada kinerja perusahaan, yaitu faktor lingkungan internal perusahaan, lingkungan eksternal dan wirausaha. Hasil studi yang dilakukan oleh Hadiyati (2008) yang menyatakan bahwa faktor - faktor lingkungan yang dibedakan dalam faktor internal dan eksternal baik langsung maupun tidak langsung berpengaruh terhadap strategi daya saing. Oleh karena itu, daya saing sangat ditentukan oleh kemampuan perusahaan dalam menerapkan orientasi kewirausahaan kedalam aktivitas strategi yang akan menentukan tujuan dan penciptaan kinerja secara superior (Hui Li, et al., 2009). Ketika UKM mampu menerapkan orientasi kewirausahaan dan inovasi, maka mereka harus mampu menyusun strategi bisnis agar dapat digunakan sebagai alat untuk menghadapi persaingan. Strategi yang tepat sangat diperlukan bagi pengusaha UKM, mengingat dalam mengembangkan usahanya dituntut kemampuan untuk mengidentifikasi peluang dan ancaman yang ada dalam lingkungan bisnisnya. Penentuan strategi bisnis yang baik akan berdampak pada pencapaian kinerja yang superior. Beberapa hasil studi empiris menunjukkan bahwa strategi bisnis akan mampu menghasilkan kinerja bagi perusahaan (seperti, Ritter dan Gemünden, 2004; Hankinson, 2000). Penelitian ini bertujuan untuk menginvestigasi peran dari orientasi kewirausahaan, inovasi dan strategi bisnis pada kinerja perusahaan. Dari penjelasan sebelumnya ditunjukkan bahwa orientasi kewirausahaan berpengaruh secara langsung terhadap kinerja perusahaan. Meskipun demikian, beberapa peneliti yang lain beranggapan bahwa variabel inovasi (seperti, Baer dan Frese, 2003) dan strategi bisnis (seperti, Ritter dan Gemünden, 2004; Hankinson, 2000) dapat dimasukkan untuk menilai kinerja perusahaan. 


\section{TINJAUAN PUSTAKA}

\section{Orientasi Kewirausahaan}

Miller (1983) menjelaskan orientasi kewirausahaan sebagai "salah satu yang terlibat dalam inovasi produk-pasar, melakukan sedikit usaha berisiko, dan pertama kali datang dengan 'proaktif' inovasi, serta memberikan pukulan untuk mengalahkan pesaing". Dalam pandangannya, Miller (1983) menyatakan bahwa orientasi kewirausahaan dapat ditentukan berdasarkan pada tiga dimensi, yaitu proactive, innovative dan risk - Taking.

Covin dan Slevin (1991) mengemukakan suatu model yang terintegrasi dan terpadu yang menjelaskan hubungan antara perilaku kewirausahaan perusahaan dengan lingkungan, strategi, faktor internal perusahaan dan dengan kinerja perusahaan. Dalam pandangannya, Covin dan Slevin (1991) menyatakan kewirausahaan akan menunjukkan perilaku standar tertentu, tercermin dalam filosofi strategis dalam praktek manajemen yang efektif.

Model Corporate Entrepreneurship dikemukan oleh Lumpkin dan Dess (2001) menyatakan bahwa ada lima dimensi Corporate Entrepreneurship yang mempengaruhi kinerja perusahaan, yaitu kebebasan, inovasi, berani menanggung resiko, proaktif, dan keagresifan bersaing. Model ini menunjukkan bahwa aspek perusahaan/korporasi akan mempengaruhi hubungan antara orientasi kewirausahaan dengan kinerja perusahaan.

\section{Inovasi}

Dalam studi literatur, Schumpeter (1934) menyebutkan bahwa terdapat lima kemungkinan jenis inovasi yang dapat dilakukan oleh perusahaan, yaitu (1) pengenalan produk baru atau perubahan kualitatif dari produk yang sudah ada, (2) proses inovasi baru bagi industri, (3) pembukaan pasar baru, (4) pengembangan sumber - sumber pasokan bahan baku baru atau input lainnya, serta (5) perubahan dalam organisasi. Berdasarkan sumbernya, Tidd, et al., (2001) menjelaskan beberapa klasifikasi dari inovasi, meliputi; inovasi yang dimulai dari munculnya organisasi (Emergent), inovasi yang diadopsi dari dalam perusahaan lain (Imported) dan inovasi yang didorong dari luar organisasi (Imposed).

Secara definitif, Amabile (1996) menjelaskan inovasi sebagai konsep yang membahas penerapan gagasan, produk atau proses yang baru. Oleh karena itu perusahaan diharapkan membentuk pemikiran - pemikiran baru dalam menghadapi baik pesaing, pelanggan dan pasar yang ada. Robbins (2002) mendefinisikan inovasi sebagai suatu gagasan baru yang diterapkan untuk memprakarsai atau memperbaiki suatu produk atau proses atau jasa. Berdasarkan penjelasan tersebut, inovasi terfokus pada tiga hal utama, yaitu : (1) gagasan baru, yaitu suatu olah pikir dalam mengamati suatu fenomena yang sedang terjadi., (2) produk atau jasa, yaitu langkah lanjutan dari adanya gagasan baru yang ditindak lanjuti dengan berbagai aktivitas, kajian, dan percobaan sehingga melahirkan konsep yang lebih konkret dalam bentuk produk dan jasa yang siap dikembangkan dan diimplementasikan, (3) upaya perbaikan, yaitu usaha sistematis untuk melakukan penyempurnaan dan melakukan perbaikan secara terus menerus.

Selanjutnya, Gatignon dan Xuerob (1997) menjelaskan bahwa dalam melakukan inovasi produk, ada 3 hal penting yang harus diperhatikan, yaitu 
keunggulan produk, keunikan produk, serta biaya produk. Produk inovasi dapat gagal karena banyak alasan. Kesalahan dalam menerapkan strategi menjadi sebab yang sering terjadi, sebab lainnya antara lain desain produk yang tidak inovatif, salah memperkirakan persaingan, masalahnya terletak pada desain atau biaya produksinya jauh lebih tinggi dari yang diperkirakan.

\section{Strategi Bisnis}

Dalam literatur usaha kecil, strategi telah disajikan kontinum mulai dari konservatif sampai proaktif-reaktif (Covin dan Slevin, 1991). Dari studi literatur tentang perencanaan strategis dan kinerja menunjukkan bahwa perusahaan secara proaktif menginvestasikan waktu dalam mengembangkan strategi dan menunjukkan tingkat kinerja yang lebih tinggi dibandingkan perusahaan yang proaktif tetapi tidak mengembangkan strategi (Covin dan Slevin, 1991).

Dalam jangka panjang, perencanaan strategi diturunkan dari usaha perusahaan untuk menciptakan keunggulan bersaing melalui strategi generik (Pearce dan Robinson, 2007) yaitu: (1) Overall Cost Leadership, (2) Differentiation, dan (3) Focus. Miles dan Snow (1978) merumuskan tipologi strategi tingkat bisnis yang melibatkan empat jenis strategis yaitu; (1) Defenders, (2) Prospectors, (3) Analyzer, dan (4) Reactor.

Hisrich, et al. (2008) menggunakan istilah strategi kewirausahaan (entrepreneurial strategy) yang didefinisikan sebagai sejumlah keputusan, tindakan, dan reaksi yang pertama-tama menciptakan, dan kemudian mengeksploitasi sebuah usaha dengan cara memaksimalkan manfaat dari kebaruan serta meminimalkan biaya. Strategi kewirausahaan mencakup strategi usaha baru maupun strategi pertumbuhan.

1. Strategi usaha baru

Merupakan penciptaan kesempatan dari suatu usaha baru, meliputi;

a. Sumberdaya sebagai sumber keunggulan kompetitif

b. Sumberdaya kewirausahaan

2. Strategi Pertumbuhan

Strategi yang fokus pada kemana harus mencari kesempatan untuk berkembang dimana perusahaan mungkin telah mempunyai dasar untuk keunggulan kompetitif yang berkesinambungan. Strategi pertumbuhan ini meliputi:

a. Strategi penetrasi

b. Strategi pengembangan pasar

c. Strategi pengembangan produk

d. Strategi diversifikasi

\section{Kinerja Perusahaan}

Dari sudut pandang teoritis, beberapa penulis memberikan artikulasi kinerja perusahaan dengan cara yang berbeda. Secara komperehensif, Mwita (2000) menjelaskan kinerja sebagai suatu keterkaitan antara variabel perilaku (processess), ouput dan outcomes (value added or impact). Chakravarthy (1986) menyatakan bahwa kinerja perusahaan merupakan sebuah konstruk yang secara umum dipergunakan untuk mengukur dampak dari sebuah orientasi strategi perusahaan. Pelham dan Wilson (1996) mendefinisikan kinerja perusahaan sebagai 
sukses produk baru dalam pengembangan pasar, di mana kinerja perusahaan dapat diukur melalui pertumbuhan penjualan dan porsi pasar.

Berdasarkan pengukurannya, Neely (1999) menjelaskan pengukuran kinerja bisnis dapat dilakukan dengan menggabungkan dua faktor, yaitu; (1) pengukuran kinerja perusahaan dapat mengadopsi ukuran yang sudah ada, (2) pengukuran kinerja harus relevan sehingga perusahaan harus selalu melakukan perubahan setiap waktu. Tsang et al., (1999) menjelaskan bahwa kinerja dapat diukur melalui kinerja keuangan, kepuasan pelanggan, proses internal dan pembelajaran serta pertumbuhan. Studi yang dilakukan oleh Bititci, et al. (2000) menjelaskan bahwa kinerja suatu bisnis dapat diukur dari; tingkat penjualan, biaya penjualan, aset yang dimiliki, citra merek dan aset tetap yang dimiliki oleh perusahaan.

\section{Kerangka Konseptual}

Dari studi empiris yang telah dilakukan, hubungan antara orientasi kewirausahaan dengan kinerja telah teruji signifikansinya. Studi awal yang menjelaskan tentang konsepsi orientasi kewirausahaan dikemukakan oleh Covin dan Slevin (1991) meliputi perilaku inovatif (innovativeness), pengambilan resiko (risk taking) dan tindakan proaktif (proactiveness).

Studi yang dilakukan oleh Lumpkin dan Dess (1996) menganggap bahwa hubungan positif antara orientasi kewirausahaan dengan kinerja tidak selalu dikaitkan dengan kesuksesan hasil. Untuk menjelaskan hubungan antara orientasi kewirausahaan dengan kinerja, Lumpkin dan Dess (1996) menggunakan dimensi innovative, risk taking, proactive, aggressiveness, dan Competitive aggressiveness. Dalam studi ini, kinerja diukur dari sales growth, market share, and profitability. Dalam studinya, Lumpkin dan Dess (1996) berusaha memasukkan faktor lingkungan sebagai variabel moderasi dari hubungan antara orientasi pasar dengan kinerja perusahaan, dan strategi sebagai variabel yang memediasi hubungan tersebut.

Orientasi kewirausahaan memberikan kontribusi terhadap kinerja dan didefinisikan sebagai sebuah ukuran majemuk yang mencakup kinerja keuangan (Wiklund, 1999). Dalam studinya, Wiklund menjelaskan bahwa terdapat hubungan positif antara orientasi kewirausahaan dengan kinerja. Kinerja diukur dari kinerja keuangan, yaitu tingkat pertumbuhan secara relatif dibandingkan dengan pesaing, melalui indikator pertumbuhan penjualan, pertumbuhan karyawan, pertumbuhan penjualan dibandingkan dengan pesaing dan pertumbuhan pangsa pasar dibandingkan pesaing. Studi lain yang dilakukan oleh Hui Li, et al. (2009) menghasilkan temuan bahwa orientasi kewirausahaan berhubungan secara positif dengan kinerja perusahaan melalui mediasi proses penciptaan pengetahuan.

Studi lanjutan yang mendukung penerapan orientasi kewirausahaan dalam hubungannya dengan kinerja perusahaan telah dilakukan oleh Galetić dan Milovanović (2004). Dalam studinya, peneliti menggunakan istilah orientasi kewirausahaan untuk merujuk pada proses pembuatan strategi dan gaya perusahaan yang terlibat dalam kegiatan wirausaha. Hasil studi menunjukkan bahwa terdapat hubungan yang positif antara orientasi kewirausahaan yang dimiliki oleh hotel di Kroasia dengan kinerja yang diukur dengan kriteria berikut : tingkat penjualan, 
tingkat pertumbuhan penjualan, arus kas, laba bersih dan kemampuan untuk mendanai pertumbuhan bisnis dari keuntungan.

Beberapa studi empiris menunjukkan bahwa inovasi berpengaruh secara langsung dan positif terhadap kinerja perusahaan. Hasil penelitian yang dilakukan oleh Bharadwaj et al (1993) menemukan bahwa kemampuan perusahaan untuk terus melakukan inovasi terhadap produk produknya akan menjaga produk tersebut tetap sesuai dengan keinginan dan kebutuhan pelanggan. Studi yang dilakukan oleh Prajogo (2006) mengeksplorasi hubungan antara inovasi dan kinerja usaha. Hasil penelitian menunjukkan bahwa (1) tidak ada perbedaan signifikan antara perusahaan manufaktur dan perusahaan jasa baik dari inovasi produk maupun inovasi proses, (2) inovasi proses menunjukkan hubungan yang relatif lebih kuat dengan kinerja usaha daripada inovasi produk dalam sektor manufaktur.

Hasil yang berbeda tentang pengaruh inovasi dan kinerja ditemukan oleh Darroch (2005). Dalam studinya, peneliti menggunakan variabel manajemen pengetahuan, inovasi dan kinerja. Hasil penelitian menunjukkan bahwa inovasi tidak mempunyai hubungan secara signifikan dengan kinerja. Penelitian yang dilakukan oleh David, et al., (2007) bertujuan untuk mengeksplorasi sifat interaksi antara dua strategi, inovasi dan orientasi pasar terhadap kinerja. Hasil penelitian menunjukkan bahwa inovasi berkorelasi secara positif dengan orientasi pasar dan kedua konstruk tersebut berkorelasi secara positif dengan kinerja perusahaan pada lingkungan yang kompetitif. Penelitian Damanpour (2001) dilakukan dengan tujuan untuk melakukan pengujian dinamika yang menentukan pengadopsian inovasi dalam produk dan proses pada perusahaan. Hasil penelitian menunjukkan bahwa adopsi inovasi produk lebih cepat daripada adopsi proses pada bank yang lebih besar, dan pengadopsian inovasi produk mempunyai hubungan positif dengan pengadopsian proses inovasi.

Penelitian Kotley, et al. (1997) bertujuan untuk menguji hubungan antara variabel nilai-nilai pribadi pemilik/manajer, strategi yang diadopsi dalam hubungannya dengan kinerja usaha. Hasil penelitiannya menunjukkan bahwa nilainilai pribadi/pemilik, strategi bisnis, secara empiris memiliki hubungan dengan kinerja. Boohene et al. (2008) meneliti tentang gender, personal values, strategies and small business performance dengan tujuan untuk menguji pengaruh gender terhadap kinerja usaha kecil di Gana dengan mengeksplorasi pengaruh personal value terhadap strategi bisnis. Pertanyaan spesifik yang ingin dijawab adalah apakah pengusaha wanita dan laki-laki memiliki perbedaan dalam penerapan strategi bisis, bagaimana nilai-nilai personal mempengaruhi strategi dan dampaknya terhadap kinerja. Hasil penelitiannya menunjukkan bahwa perbedaan karakteristik personal akan menentukan perbedaan strategi yang diambil, yang pada akhirnya berpengaruh terhadap kinerja usaha. Suci (2009) meneliti tentang peningkatan kinerja melalui orientasi kewirausahaan, kemampuan manajemen, dan strategi bisnis. Hasil analisis menunjukkan bahwa strategi bisnis dipengaruhi oleh keterampilan manajemen UKM dan selanjutnya akan mempengaruhi kinerja. Sedangkan hasil penelitian Hashim (2000) menemukan bahwa kinerja SMEs di Malaysia bervariasi dengan perbedaan pilihan strategi bisnis yang diadopsi. 


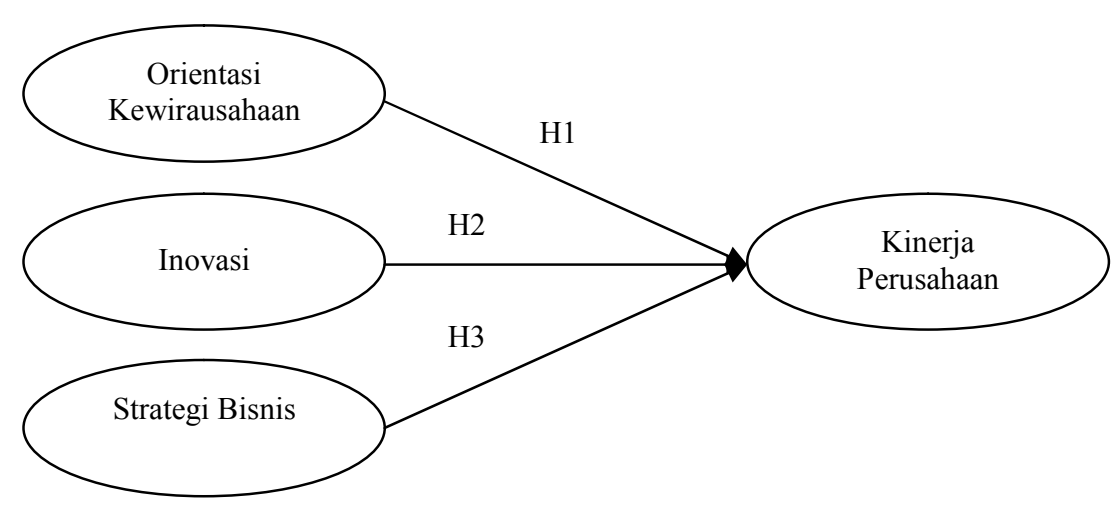

Gambar 1. Kerangka Konseptual Penelitian

\section{Hipotesa Penelitian}

Berdasarkan penjelasan diatas maka hipotesa penelitian dapat diajukan sebagai berikut ;

1. Orientasi kewirausahaan berpengaruh secara langsung terhadap kinerja perusahaan.

2. Inovasi berpengaruh secara langsung terhadap kinerja perusahaan.

3. Strategi bisnis berpengaruh secara langsung terhadap kinerja perusahaan.

\section{METODE}

Penelitian ini dilakukan pada usaha kecil menengah yang berada di wilayah Kabupaten Malang. Lokasi penelitian ini ditentukan pada UKM Sentra di Kabupaten Malang dan terdaftar di Dinas Perindustrian dan Perdagangan tahun 2011. Kriteria dari Usaha Kecil Menengah yang digunakan adalah :

1. UKM yang terdaftar/mempunyai ijin usaha dan dapat diidentifikasi oleh Dinas Perindustrian dan Perdagangan Kabupaten Malang.

2. UKM yang bergerak di bidang manufaktur, yaitu Usaha Kecil Menengah yang menghasilkan produk.

3. UKM yang menjadi produk andalan dan potensial untuk dikembangkan.

Berdasarkan kriteria tersebut, maka populasi pada penelitian adalah UKM sentra yang bergerak di bidang pengolahan pangan. Populasi jumlah populasi yang digunakan pada penelitian ini sebesar 468 unit usaha.

Sampel pada penelitian ini ditentukan berdasarkan rumus dari Slovin (Husein Umar, 1997) dengan mengasumsikan populasi berdistibusi normal dan tingkat kesalahan pengambilan sampel sebesar $10 \%$. Berdasarkan perhitungan, maka jumlah sampel yang digunakan pada penelitian ini sebesar 82,394 UKM (pembulatan 100 UKM). Pengambilan sampel dilakukan dengan metode probability sampling, dengan teknik Proportional Random Sampling.

Penelitian ini menggunakan data primer dan data sekunder. Data primer dikumpulkan melalui penyebaran kuesioner kepada responden, yaitu pemilik atau manajer dari Usaha Kecil Menengah, dengan berdasarkan pada instrumen 
penelitian. Sedangkan data sekunder diperoleh melalui Pemerintah Kabupaten Malang dan Dinas Kabupaten bidang usaha kecil menengah, BPS, serta instansi terkait. Variabel-variabel yang digunakan dalam penelitian ini adalah orientasi kewirausaahaan, inovasi, strategi bisnis, kinerja perusahaan. Metode analisis data yang digunakan untuk menjawab rumusan masalah dalam penelitian ini adalah Regresi Berganda dengan menggunakan sofware SPSS versi 16. Regresi linier berganda bertujuan untuk menunjukkan hubungan antara variabel tergantung (Y) terhadap variabel bebas $\left(\mathrm{X}_{1}, \mathrm{X}_{2}, \mathrm{X}_{3}\right)$, untuk mengetahui pengaruh orientasi kewirausahaan, inovasi, strategi bisnis dan kinerja perusahaan.

\section{PEMBAHASAN}

UKM sentra di Kabupaten Malang, pengolahan makanan menjadi sektor yang sangat strategis dalam meningkatkan perekonomian daerah di Kabbupaten Malang. Meskipun sektor ini masih didominasi oleh industri rumah tangga, tetapi sektor ini mampu menyerap jumlah tenaga kerja sebesar 30,11\%. Jumlah ini memang lebih kecil jika dibandingkan dengan serapan tenaga kerja yang ada pada sektor kimia dan bahan bangunan. Dari hasil survey menggambarkan bahwa kecilnya jumlah serapan tenaga kerja pada sektor pengolahan makanan disebabkan karena kecilnya jumlah kecukupan tenaga kerja yang dibutuhkan, terutama untuk kegiatan produksi. Tetapi jika melihat potensi pengembangannya, sektor pengolahan makanan masih sangat terbuka. Hal ini disebabkan karena bahan baku utama yang digunakan untuk menghasilkan produk berasal dari hasil pertanian. Berdasarkan jenis produk yang dihasilkan, UKM sentra pengolahan makanan memproduksi beberapa jenis makanan hasil pertanian, seperti emping melinjo, kerupuk, tempe, tahu dan rengginang. Dari informasi yang diperoleh melalui Dinas Perindustrian dan Perdagangan Kabupaten Malang menunjukkan bahwa potensi pertanian di wilayah Kabupaten Malang sangat beraneka-ragam dan tersebar di seluruh kecamatan. Oleh karena itu, dengan bahan baku utama yang mudah diperoleh dan tersedia cukup banyak menyebabkan usaha yang bergerak pada sektor pengolahan makanan seharusnya mempunyai posisi persaingan yang sangat strategis dalam menghasilkan produk yang berbiaya rendah, dan pada akhirnya akan mampu membawa mereka untuk memperolah daya saing. Orientasi kewirausahaan merupakan komponen yang sangat penting dalam mengembangkan usaha hal terlihat dari pemilik dan pengelola dalam menjalankan usahanya sudah menunjukkan perilaku inovatif, proaktif dan berani dalam mengambil resiko. Inovasi merupakan komponen yang sangat penting dalam upaya pengembangan usaha. Tanpa adanya inovasi, suatu usaha akan sulit untuk dapat bersaing dengan perusahaan lain. Strategi bisnis merupakan komponen yang sangat penting dalam upaya untuk bersaing dengan perusahaan lain dengan penentuan strategi bisnis, meliputi strategi penetrasi, strategi pengembangan pasar, strategi pengembangan produk dan strategi diversifikasi sehingga pada akhirnya kinerja yang dicapai oleh UKM dalam menjalankan kegiatan usaha telah terpenuhi.

Hasil uji hipotesis menunjukkan bahwa orientasi kewirausahaan berpengaruh secara positif dan signifikan terhadap kinerja perusahaan. Hasil ini 
memberi makna bahwa semakin baik orientasi kewirausahaan yang dimiliki oleh UKM Sentra, seperti perilaku inovatif, perilaku proaktif dan pengambilan resiko, maka pencapaian kinerja perusahaan juga akan semakin baik. Dengan orientasi kewirausahaan yang semakin kuat maka akan membantu perusahaan dalam menciptakan ide baru, membuka peluang untuk melakukan penetrasi pasar dan melakukan percobaan meskipun beresiko, sehingga pada akhirnya dapat menjadi pemimpin pasar dengan melaksanakan strategi dan tujuan jangka panjang. Temuan ini memberikan gambaran bahwa UKM Sentra di Kabupaten Malang telah melakukan upaya penerapan orientasi kewirausahaan sebagai landasan dalam menjalankan aktivitas bisnis. Melalui proses tersebut, UKM Sentra terbukti mampu merespons perubahan lingkungan melalui penerapan orientasi kewirausahaan yang baik sehingga mampu bertahan.

Temuan yang dihasilkan dalam penelitian ini konsisten dengan konsepsi dari Miller (1983), serta Covin dan Slevin (1989) bahwa orientasi kewirausahaan yang terkait dengan perilaku inovatif, perilaku proaktif dan keberanian mengambil risiko mampu meningkatkan kinerja usaha. Demikian juga, hasil penelitian ini mendukung temuan empiris dari Bacherer dan Maurer (1997), Suci (2008) yang menemukan adanya pengaruh positif dan signifikan antara orientasi kewirausahaan terhadap kinerja perusahaan. Peneliti lainnya, Lee dan Tsang (2001) dan Ferreira dan Azevedo (2007) menyampaikan hasil temuannya bahwa kemampuan kewirausahaan yang tercermin dari perilaku pengelola sebagai determinan penting dalam meningkatkan pertumbuhan usaha.

Identifikasi konsep orientasi kewirausahaan berkaitan dengan pencapaian kinerja perusahaan dapat dikaji melalui indikator-indikator yang digunakan. Dari hasil analisis deskriptif ditunjukkan bahwa pengambilan resiko merupakan komponen utama yang menentukan orientasi kewirausahaan. Covin dan Slevin (1989) berpendapat bahwa lingkungan yang dihadapi oleh perusahaan tidak stagnan, sehingga tidak secara esensial akan menghasilkan kinerja yang superior, bahkan memungkinkan akan menghasilkan resiko bagi perusahaan. Selanjutnya, Miller (1983) berpendapat bahwa dengan orientasi kewirausahaan maka wirausaha akan menunjukkan eksistensinya dalam bentuk keberanian dalam mengambil resiko, melakukan perubahan dan mengeksploitasi perilaku inovatif untuk memperoleh keunggulan bersaing. Pernyataan tersebut mengindikasikan bahwa resiko yang mungkin diterima oleh perusahaan merupakan bagian yang tidak terpisahkan dengan perubahan lingkungan. Oleh karena itu, kekuatan UKM Sentra dalam mengambil resiko akan mendorong perusahaan untuk bekerja dengan lebih keras sehingga tingkat keuntungan dapat dicapai.

Hasil uji hipotesis menunjukkan bahwa inovasi berpengaruh secara positif dan signifikan terhadap kinerja perusahaan. Hasil ini memberi makna bahwa semakin baik inovasi yang dimiliki oleh UKM Sentra maka pencapaian kinerja perusahaan juga akan semakin baik. Dengan inovasi yang kuat maka akan membantu perusahaan dalam pengembangan ide tentang produk baru, fokus pada upaya untuk menghasilkan produk serta selalu berupaya untuk memasarkan produk yang variatif di pasar. Pada akhirnya, inovasi yang telah dilakukan dapat digunakan sebagai landasan bagi perusahaan untuk mencapai keunggulan kompetitif dalam jangka panjang. Temuan ini memberikan gambaran bahwa UKM Sentra di Kabupaten Malang telah melakukan upaya penerapan inovasi 
sebagai landasan dalam menjalankan aktivitas bisnis. Melalui proses tersebut, UKM Sentra terbukti mampu mengembangkan produk baru serta melakukan modifikasi pada pasar sehingga mampu bertahan.

Temuan yang dihasilkan dalam penelitian ini sejalan dengan hasil studi dari Baer dan Frese (2003) bahwa inovasi dianggap sebagai komponen yang dapat memberikan manfaat bagi perusahaan dalam mencapai keunggulan bersaing. Selanjutnya, inovasi yang diukur dari proses produksi, produk yang dihasilkan, pemikiran baru dalam organisasi mempunyai hubungan erat dengan kemampuan inovasi perusahaan sehingga mendorong peningkatan kinerja (Hurley dan Hult, 1998; Hurley et al, 2003). Hasil penelitian ini juga memperluas hasil penelitian yang dilakukan oleh Prajogo (2006) yang menemukan adanya hubungan positif antara inovasi dan kinerja. Pada penelitian ini, inovasi diukur dari inovasi produk dan inovasi proses.

Hasil uji hipotesis menunjukkan bahwa strategi bisnis berpengaruh secara positif dan signifikan terhadap kinerja perusahaan. Hasil ini memberi makna bahwa semakin baik strategi bisnis yang dimiliki oleh UKM Sentra maka pencapaian kinerja perusahaan juga akan semakin baik. Dengan strategi bisnis yang semakin kuat maka akan membantu perusahaan dalam menciptakan ide baru, membuka peluang untuk melakukan penetrasi pasar dan melakukan percobaan meskipun beresiko, sehingga pada akhirnya dapat menjadi pemimpin pasar dengan melaksanakan strategi dan tujuan jangka panjang. Temuan ini memberikan gambaran bahwa UKM Sentra di Kabupaten Malang telah melakukan upaya penerapan strategi bisnis sebagai landasan dalam menjalankan aktivitas bisnis. Melalui proses tersebut, UKM Sentra terbukti mampu merespons perubahan lingkungan melalui penerapan strategi bisnis yang baik sehingga mampu bertahan.

Temuan yang dihasilkan dalam penelitian ini konsisten dengan konsepsi dari Porter (1980); Barney (1991; 1997) bahwa strategi bisnis mampu meningkatkan kinerja usaha. Hasil ini juga sejalan dengan studi yang dilakukan oleh Covin dan Slevin (1991) dimana kinerja perusahaan kecil tergantung dari strategi yang mereka gunakan. Studi ini memberikan makna bahwa kemampuan dari usaha kecil untuk merumuskan dan menerapkan strategi yang efektif memiliki pengaruh yang besar terhadap kelangsungan hidup atau kegagalan usaha kecil.

Secara teknis, tindakan awal yang dapat dilakukan oleh UKM dalam menyusun strategi bisnis adalah dengan meningkatkan kemampuan dari sumber daya manusia yang dimiliki, baik melalui pelatihan, seminar ataupun lokakarya, yang akan meningkatkan kompetensinya. Penekanan pada peningkatan kemampuan dari sumber daya manusia yang dimiliki oleh UKM dalam menyusun strategi bisnis diperkuat dengan pendapat dari Tan dan Wang (2010) bahwa dalam perspektif Resource-Based View (RBV), kepemilikan sumberdaya yang superior akan menyebabkan perusahaan mampu menciptakan nilai ekonomi yang lebih baik daripada pesaing. Implikasinya, RBV akan menghasilkan keunggulan bersaing dalam jangka panjang bagi perusahaan pada situasi pasar yang dinamis. Dengan demikian, kemampuan dan komitmen yang kuat untuk menggenerasi dan memanfaatkan sumber daya yang dikuasai akan menghantarkan UKM untuk meningkatkan kinerja usaha secara terus menerus. 


\section{KESIMPULAN}

Dari hasil penelitian ini dapat ditarik beberapa kesimpulan sebagai berikut;

1. Peningkatan kinerja UKM Sentra di Kabupaten Malang tidak terlepas dari kemampuan pengusaha dalam memahami orientasi kewirausahaan, inovasi dan strategi bisnis. Meskipun demikian, pemahaman UKM Sentra dalam menerapkan orientasi kewirausahaan, kegiatan yang inovatif dan menyusun strategi bisnis masih perlu ditingkatkan.

2. Dari hasil uji hipotesis membuktikan bahwa orientasi kewirausahaan berpengaruh secara langsung dan positif terhadap kinerja perusahaan. Temuan lain yang dihasilkan dari pengujian hipotesis menunjukkan bahwa inovasi berpengaruh secara langsung dan positif terhadap kinerja perusahaan. Selanjutnya, hasil penelitian ini juga menemukan bahwa strategi bisnis akan mempengaruhi pencapaian kinerja perusahaan. Hal ini bermakna bahwa semakin kuat orientasi kewirausahaan, inovasi dan strategi bisnis yang dimiliki oleh perusahaan, maka akan meningkatkan kinerja perusahaan.

3. Secara keseluruhan, hasil penelitian menunjukkan bahwa orientasi kewirausahaan, inovasi dan strategi bisnis berpengaruh secara signifikan terhadap kinerja perusahaan.

\section{SARAN}

Berdasarkan hasil penelitian, pembahasan, dan keterbatasan penelitian, maka dapat dikemukakan saran-saran sebagai berikut :

1. Dengan menilai pentingnya pemahaman UKM Sentra tentang orientasi kewirausahaan, maka mereka harus lebih memahami makna penting dari penerapan perilaku tersebut. Oleh karena itu, UKM Sentra harus dapat lebih memahami arti penting dari optimalisasi sumberdaya yang dimiliki, baik sumberdaya keuangan maupun sumberdaya manusia, selalu melakukan langkah - langkah antisipatif terhadap perubahan lingkungan serta selalu selalu terfokus pada upaya pengembangan pasar dan produk yang dihasilkan. Pada dasarnya, UKM harus selalu berusaha untuk memberikan nilai tambah pada produk yang dihasilkan serta selalu berusaha untuk memberikan pelayanan yang terbaik kepada pelanggan. Selain itu, keberadaan dari pesaing, baik pesaing yang sudah ada maupun pesaing potensial, juga harus lebih diperhatikan.

2. Perilaku yang inovatif, perilaku proaktif dan keberanian dalam mengambil resiko usaha berperan sangat penting dalam menunjang keberhasilan penerapan perilaku orientasi kewirausahaan. Hal ini memberikan petunjuk bagi UKM Sentra untuk mengedepankan perilaku inovatif, perilaku proaktif dan keberanian dalam mengambil resiko usaha melalui peningkatan kemampuan dan ketrampilan dari sumberdaya yang dimiliki oleh organisasi. Peningkatan kemampuan UKM Sentra pada perilaku inovatif, perilaku proaktif dan keberanian mengambil resiko dapat dilakukan dalam bentuk peningkatan kemampuan dalam menjalankan usaha, kemampuan karyawan dalam menunjukkan ide-ide kreatif, kemampuan dalam membuka peluang melalui 
perluasan pasar. Melalui beberapa bentuk peningkatan kemampuan tersebut diharapkan kinerja perusahaan dapat ditingkatkan.

3. Tindakan yang inovatif dan penentuan strategi bisnis merupakan komponen yang sangat penting untuk menentukan keberlanjutan usaha. Oleh karena itu, UKM Sentra harus selalu berupaya untuk mencari cara-cara memasarkan produk atau jasa dengan lebih baik, menjalankan bisnis dengan menghasilkan produk atau jasa dengan atribut yang berbeda dari pesaing serta memanfaatkan teknologi guna menghasilkan barang lebih efektif dan efisien. Selain itu, perlu juga dipertimbangkan untuk menciptakan unit usaha baru yang dapat digunakan untuk meminimalisir tingkat resiko yang mungkin diterima

\section{DAFTAR PUSTAKA}

Amabile, Teresa M.,1996, Assesing The Work Environment For Creativity, Academy of Management Journal, p.1154 - 1184.

Baer, Markus dan Michael Frese, 2003, Innovation Is Not Enough: Climates For Initiative And Psychological Safety, Process Innovations, And Firm Performance, J. Organiz. Behav. 24, 45-68.

Bharadwaj, Sundar G, P.R.Varadarajan dan Fahly Jihn, 1993, Sustainable Competitive Advantage in Service Industries: A Conceptual Model and Research Propositions, Journal of Marketing, Vol. 57, p.83 - 99.

Bititci, Umit S., Trevor Turner dan Carsten Begemann, 2000, Dynamics of performance measurement systems, International Journal of Operations \& Production Management, Vol. 20 No. 6, pp. 692-704.

Boohene, Rosemond, Alison Sheridan and Bernice Kotey, 2008, Gender, Personal Values, Strategies And Small Business Performance. Equal Opportunities International, Vol. 27 No. 3, pp. $237-257$.

Chakravarthy, Balaji S., 1986, Measuring Strategic Performance, Strategic Management Journal, Vol. 7, No. 5, pp. 437-458.

Covin, Jeffrey G. dan Dennis P. Slevin, 1989, Strategic Management of Small Firms in Hostile and Benign Environments, Strategic Management Journal, Vol. 10, No. 1., pp. 75-87.

Covin, Jeffrey G. dan Dennis P. Slevin, 1991, A Conceptual Model of Entrepreneurship As Firm Behavior, Baylor University.

Damanpour, Fariboz., 2001, The Dynamics Of The Adoption Of Product And Process Innovation In Organization, Lag. Administrative Science Quarterly $29 ; 329-409$. 
Darroch, Jenny, 2005, Knowledge Management, Innovation and Firm Performance, Journal of Knowledge Management, Vol. 9 Iss. 3. Pp. $101-115$.

Galetić, Fran dan Bojan Morić Milovanović, 2004, Linking Entrepreneurial Orientation With The Performance Of Croatian Hotel Industry, Faculty of Economics and Business, Working Paper, 2004.

Gatignon, Hubert dan Jean - Marc Xuerob, 1997, Strategic Orientation of The Firm and new Product Performance, Journal of Marketing Research. p.7779 .

Hisrich, Robert D., Michael P. Peter, dan Dean A. Shepherd, 2008, Entrepreneurship. Chriswan Sungkono dan Diana Angelica (penerjemah), Kewirausahaan, Salemba Empat, Jakarta.

Hankinson, Alan, 2000, The Key Factors In The Profiles Of Small Firm Owner Managers That Influence Business Performance; The South Coast Small Firms Survey, Industrial and Commercial Training, Vol 32 No 3.

Harris, Lloyd C., 2001, Market Orientation And Performance: Objective And Subjective Empirical Evidence From UK Companies, Journal of Management Studies 38:1 January 2001 0022-2380.

Hashim, M.K. 2000, Business Strategy And Performance In Malaysian SMEs: a recent survey, Malaysian Management Review, pp. 1-10.

Hui Li, Yong, Jing-Wen Huang dan Ming-Tien Tsai, 2009, Entrepreneurial Orientation And firm Performance: The Role Of Knowledge Creation Process, Industrial Marketing Management, 38 pp. 440-449.

Hurley, R.F. and Hult, G.T.M., 1998, Innovation, Market Orientation, And Organizational Learning: An Integration And Empirical Examination, Journal of Marketing, Vol. 62, pp. $42-54$.

Husband, S. dan Purnendu, M., 1999. A Conceptual Model for Quality Inetgrated Management in Small and Medium Size Enterprise, International Journal of Quality \& Reliability Management, Vol. 16 No. 7, pp. 699-713.

Kotley, B and Meredith, G.G, 1997, Relationship Among Owner/Manager Personal Values And Perceptions, Business Strategis, And Enterpreise Performance, Journal of Small Business Management, Vol. 35, No. 2, pp. 37-64.

Lumpkin, G. T. dan Gregory G. Dess, 1996, Clarifying the Entrepreneurial Orientation Construct and Linking It to Performance, The Academy of Management Review, Vol. 21, No. 1, (Jan., 1996), pp. 135-172.

Lumpkin, G.T. dan Gregory G. Dess, 2001, Linking Two Dimensions Of Entrepreneurial Orientation To Firm Performance: The Moderating Role 
Of Environment And Industry Life Cycle, Journal Of Business Venturing $16: 429-451$.

Mahemba, C. M. (2003), Innovation Management Practices of Small and Medium Scale Enterprises In Tanzania, PhD Dissertation, University of Twente, Enschede.

Miller, Danny., 1983, The Correlates Of Entrepreneurship In Three Types Of Firms, Management Science, 29: 770-791.

Mwita, Isaac John, 2003, Performance Management Model, The International Journal of Public Sector Management, MCB University Press, Vol.13 (1).

Pearce, J.A., dan Robinson Jr. R.B., 2007, Strategic Management Formulation, Implementation, and Control, 10th ed. McGraw-Hill.

Prajogo, Daniel I., 2006, The Relationship Between Innovation And Business Performance - A Comparative Study Between Manufacturing And Service Firms, Knowledge and Process Management, Vol. 13 Iss. 13, pp. 218 225.

Porter, M.F. 1980, Competitive Strategy, The Free Press, New York, NY.

Ritter, Thomas dan Hans Georg Gemünden, 2004, The impact of a Company's business strategy on its technological competence, network competence and innovation success, Journal of Business Research 57,p. 548- 556.

Robbins, Stephen, 2002, Perilaku Organisasi; Konsep, Kontroversi, Aplikasi, Alih Bahasa Hadyana Pujatmaka dan Benyamin Molan, PT. Prehallindo, Jakarta.

Suci, Rahayu Puji, 2009, Peningkatan Kinerja Melalui Orientasi Kewirausahaan, Kemampuan Manajemen, dan Strategi Bisnis, Jurnal Manajemen dan Kewirausahaan, Vol. 11 No. 1 pp. 46-58.

Tambunan, Tulus,2005, Promoting Small and Medium Enterprises with a Clustering Approach: A Policy Experience from Indonesia, Journal of Small Business Management, Vol 43 No. 2, pp.138-154.

Tambunan, Tulus, 2008, Ukuran Daya Saing Koperasi Dan UKM, Study RPJM Nasional Tahun 2010-2014 Bidang Pemberdayaan Koperasi dan UKM, Bappenas.

Tidd, Joe, 2001, Innovation Management in context ; environment, organization and performance, International Journal of Management Reviews, Vol. 3 Issue 3, pp. $169-183$. 
Tsang, Albert H.C., Andrew K.S. Jardine dan Harvey Kolodny, 1999, Measuring maintenance performance: a holistic approach, International Journal of Operations \& Production Management, Vol. 19 No. 7, 1999, pp. 691-715.

Umar, Husein, 2001, Metode Penelitian Untuk Skripsi Dan Tesis Bisnis, Cetakan Keempat, PT. Raja Grafindo Persada, Jakarta.

Wiklund, Johan, 1999, The Sustainability of the Entrepreneurial Orientation-Performance Relationship, Entrepreneurship: Theory and Practice - 1999.

Wiklund, Johan dan Dean Shepherd, 2005, Entrepreneurial Orientation And Small Business Performance : A Configurational Approach, Journal of Business Venturing 20 (2005) 71-91. 